\title{
NOVO CPC E SUA APLICAÇÃO AO PROCESSO DO TRABALHO
}

NEW CPC AND ITS APPLICATION TO THE WORK PROCESS

Bruno Luís Costa SILVA ${ }^{1}$

ISSUE DOI: $10.21207 / 1983.4225 .377$

\section{RESUMO}

O Processo do Trabalho, caminho pelo qual se busca a tutela de um direito trabalhista, deve ter como essência os preceitos máximos da Constituição que resguardam direitos fundamentais aos seres humanos. Nem mesmo as constantes mudanças ocasionadas pela evolução da sociedade devem mitigar a função protetiva inerente a este procedimento. Este até pode sofrer alterações, mas as mudanças devem estar de acordo com o que preceitua o Direito do Trabalho. Relacionado a essas mudanças, surge o Novo Código de Processo Civil, trazendo diversas inovações em relação ao código anterior. Mesmo não existindo uma relação direta com o Processo do Trabalho, o artigo 769 da Consolidação das Leis do Trabalho já apresentava a hipótese de se utilizar o procedimento civil em casos que necessitassem de complemento. Com o advento do Novo CPC, a regra passou a existir também na codificação processual civil em seu artigo 15, prevendo que, na ausência 
de normas que regulem processos trabalhistas, as disposições do procedimento comum lhes serão aplicadas supletiva e subsidiariamente. Com base nas novas discussões sobre o tema, o objetivo essencial deste artigo está em apresentar, através de regras de hermenêutica, as possíveis aplicações do Novo Código de Processo Civil ao Processo do Trabalho, seguindo para isto os regramentos presentes nos princípios que regem a matéria trabalhista. Com este enfoque, o trabalho apresentado resultou no entendimento de que não se pode utilizar o Novo CPC, ante sua aplicação suplementar ou subsidiária ao Processo do Trabalho, em casos em que o trabalhador fique desprotegido ou diante de uma condição menos benéfica.

Palavras-chave: Processo do trabalho. Processo civil. Fundamentação das decisões judiciais. Distribuição dinâmica do ônus da prova. Incidente de desconsideração da personalidade jurídica.

\section{ABSTRACT}

The Labor Process, the path by which the protection of a labor right is sought, must have as its essence the maximum precepts of the Constitution that safeguard fundamental rights for human beings. Not even the constant changes brought about by the evolution of society must mitigate the protective function inherent in this process. This may even change, but the changes must be in accordance with what Labor Law prescribes. Relating to these changes, the New Code of Civil Procedure arises, bringing various innovations in relation to the previous code. Even if there is no direct relationship with the Labor Process, Article 769 of the Consolidation of Labor Laws already provided for the possibility of using the civil procedure in cases that needed to be supplemented. With the advent of the New CPC, the rule also came into existence in the civil procedural codification in its article 15, providing that, in the absence of rules governing labor proceedings, the provisions of the common procedure will be applied to them in a subsidiary and subsidiary manner. Based on the new discussions on the subject, the main objective of this article is to present, through rules of hermeneutics, the possible applications of the New Code of Civil Procedure to the Labor Process, following the rules in the principles governing Labor matters. With this approach, the presented work resulted in the understanding that it is not possible to use the New CPC, with its supplementary or 
subsidiary application to the Labor Process, in cases where the worker is unprotected or in the face of a less beneficial condition.

Keywords: Work process. Civil lawsuit. Grounds for judicial decisions. Dynamic distribution of the burden of proof. Incident of disregard of legal personality.

\section{INTRODUÇÃO}

As normas trabalhistas devem se revestir de celeridade e de uma real justiça. A primeira por se relacionar com a eficiência, pois um caminho simples para se alcançar algum direito impede que ocorram danos imediatos ou mediatos ao trabalhador, fornecendo-lhe a tutela de maneira célere. A outra porque nem sempre um fato apresentado será realmente o ocorrido. Por vezes, uma falta de prova pode ocasionar um dano irreparável, sendo necessária, assim, a existência de princípios e presunções que possam prevenir uma injustiça. Tais presunções não devem ser vistas como afronta ao direito de uma das partes, mas a garantia de proteção à situação real de determinada relação trabalhista.

Com base nisto, o Processo do Trabalho, caminho com o qual se busca a tutela de um direito trabalhista, deve ter como essência os preceitos tratados acima. Não se pode tentar garantir algum direito sem fornecer uma oportunidade concreta de atendê-lo. O procedimento trabalhista, portanto, revela-se como guardião das disposições do Direito do Trabalho, além de, por consequência de sua proteção ao Direito Material a que se relaciona, resguardar direitos fundamentais dos trabalhadores apresentados pela Constituição. Nem mesmo as constantes mudanças ocasionadas pela evolução da sociedade devem mitigar a função protetiva da esfera trabalhista. Este até pode sofrer alterações, mas as mudanças devem estar de acordo com o que preceitua o Direito do Trabalho.

Relacionado a essas mudanças, surge o Novo Código de Processo Civil. A Lei 13.105/15 trouxe diversas inovações em praticamente todos os temas que tratava o Código de 1973. Dentre as novidades está a criação do incidente de desconsideração da personalidade jurídica, instituto que se embasa, a priori, a consecução do contraditório e ampla defesa para o sócio ou pessoa jurídica afetada pela desconsideração. Como algo inovador que ainda não fora colocado em prática, profissionais do direito passaram a estudar as disposições deste incidente, tecendo críticas e elogios. 
Vale lembrar que, mesmo o processo civil não possuindo uma relação direta com o Processo do Trabalho, o artigo 769 da Consolidação das Leis do Trabalho já apresentava a hipótese de se utilizar o procedimento comum em casos que necessitassem de complemento ao dizer que nos casos omissos, o direito processual comum será fonte subsidiária do direito processual do trabalho, exceto naquilo em que for incompatível com as normas deste Título. Com o advento do Novo CPC, a regra passou a existir também na codificação processual civil em seu artigo 15, prevendo "Na ausência de normas que regulem processos eleitorais, trabalhistas ou administrativos, as disposições deste Código lhes serão aplicadas supletiva e subsidiariamente". Surgem então novas discussões acerca do tema, com diversas teses da extensão que teriam tais normas ao se relacionarem. Dentre os debates existentes, está o da aplicação ou não do incidente de desconsideração da personalidade jurídica, bem como seus efeitos na execução trabalhista.

A execução no campo trabalhista prima pela efetividade e celeridade em prol da dignidade humana do trabalhador. Deste modo, a aplicação de regras nas fases de conhecimento e execução deve buscar o meio mais rápido, porém através da melhor forma de tutela do direito. A hermenêutica, portanto, é um dos primeiros passos para se assegurar uma prestação jurisdicional justa. Passado pelo caminho de uma interpretação correta, a trajetória deve visar a essência da execução no Processo do Trabalho para, logo a seguir, compreender se a aplicação desse novo instituto é revestida de legalidade e de valoração.

\section{PRINCÍPIOS REGULADORES DO PROCESSO DO TRABALHO}

De nada adiantariam os direitos materiais resguardados pelo Direito do Trabalho sem a existência de um meio efetivo para tutelá-los. Um caminho para se chegar ao seu fim máximo, isto é, dizer o direito na esfera trabalhista e proteger as desigualdades extremas ocasionadas pela relação subordinada de trabalho. Motivado por tal necessidade, surge o procedimento desse ramo jurídico. Assim, o Processo do Trabalho nada mais é que um percurso que torna efetivo os preceitos de caráter material presentes na CLT. Devido à sua importância, o processo trabalhista deve estar atrelado 
a princípios gerais (que auxiliam a teoria geral do processo) e específicos, os quais norteiam a esfera trabalhista.

Dentre os princípios gerais, possuem destaque os seguintes: a) devido processo legal; b) duração razoável do processo; c) fundamentação (motivação) das decisões do Poder Judiciário; d) juiz natural. Esses princípios, por terem caráter constitucional, revelam uma essência que fora sempre existente, mas que apenas nos últimos anos se tornou alvo de teses e debates: por seguirem os preceitos da Constituição Federal, na qual a Justiça é o fim último de um Estado Democrático de Direito, sendo assim um valor supremo, o processo é simplesmente um instrumento para efetividade da justiça, uma engrenagem que deve se movimentar através da Constituição de maneira eficiente a tutelar seu direito material relacionado.

Analisando o primeiro princípio, o devido processo legal revela que "ninguém será privado da liberdade ou de seus bens sem o devido processo legal" (art. 5', LIV, C.F). Como bem posiciona Ada Pellegrini Grinover², "a justiça penal e a civil são informadas pelos dois grandes princípios constitucionais: o acesso à justiça e o devido processo legal. Destes decorrem todos os demais postulados necessários para assegurar o direito à ordem jurídica justa". Deste modo, o referido preceito assegura a efetividade dos demais, já que todo princípio processual deve prezar por um devido processo de acordo com a lei. No âmbito do procedimento trabalhista, o devido processo legal se revela como base para o contraditório e a ampla defesa, além de dar concretude à igualdade material entre as partes, tendo em vista, por exemplo, a oralidade e o "jus postulandi" como preceitos que deixam o reclamante em estado de igualdade.

Em relação à duração razoável do processo, esta se faz presente na Constituição Federal, art. $5^{\circ}$, inciso LXXVIII, em que "a todos, no âmbito judicial e administrativo, são assegurados a razoável duração do processo e os meios que garantam a celeridade de sua tramitação". Interpretando tal disposição, conclui-se que o devido processo legal, que tutele de maneira eficaz o direito através da prestação jurisdicional em tempo hábil, é o meio mais eficiente de se fazer justiça, pois não há justiça tardia. De acordo com a Professora Ada Pellegrini Grinover, a determinação de tal princípio deve levar em conta três critérios: a complexidade do assunto, a atuação do órgão jurisdicional e o comportamento dos litigantes. Na esfera

\footnotetext{
${ }^{2}$ GRINOVER, Ada Pellegrini. Teoria Geral do Processo. Malheiros Editores, $22^{a}$ ed. São Paulo, 2006. p. 112.
} 
trabalhista, a duração razoável do processo é preceito de extrema importância, tendo em vista o caráter alimentar presente no direito do reclamado. Deste modo, uma prestação jurisdicional que se perdura no tempo sem dar uma solução ao processo pode causar danos irreparáveis aos trabalhadores que por muitas vezes dependem do Judiciário para adquirirem o sustento que lhes é de direito.

Sobre o terceiro princípio geral a ser tratado, o da motivação das decisões judiciais, a professora Ada Pellegrini Grinover nos revela dois períodos em que existiram diferentes interpretações. O primeiro período, que fora influenciado pelo pensamento tradicional, defendia a tese de que a fundamentação do Poder Judiciário era uma garantia das partes, fornecendo uma possibilidade de impugnar tal decisão. Atualmente, prevalece a interpretação do referido princípio através de sua função política, em que além das ideias do pensamento tradicional, se incluiria a finalidade da motivação das decisões judiciais como um meio para se concretizar a imparcialidade do juiz, a legalidade e justiça das decisões ${ }^{3}$. Da mesma forma, um processo trabalhista que realmente demonstre uma decisão justa deve se basear nos fundamentos legais, jurisprudenciais e axiológicos para que o verdadeiro direito do trabalhador, depois de decretado, passe à etapa de sua efetivação.

Seguindo a análise do último preceito a ser tratado neste tópico, o princípio do juiz natural, além de proibir a criação de tribunais de exceção, também estabelece que somente o juiz seja investido de jurisdição. Com base nisto, não há possibilidade de integrantes dos demais poderes senão o do Judiciário, de dizerem o direito no caso concreto. Atualmente, incluíram-se a esse princípio as ideias de que somente será órgão jurisdicional aquele instituído pela Constituição e que o juiz não só deve ser investido antes da ocorrência do fato, como existem distribuições de competência entre os julgadores, organizando suas áreas de atuação. Quanto à Justiça do Trabalho, o juiz deve seguir os requisitos expostos anteriormente, com margem de atuação focada, com algumas exceções, às ações oriundas de descumprimento das normas trabalhistas ou constitucionais e daquelas que estão ligadas à relação de emprego.

No que tange aos preceitos específicos do Processo do Trabalho, em seu artigo $1^{\circ}$, inciso IV, a Carta Magna de 1988 dispõe sobre um dos

\footnotetext{
${ }^{3}$ GRINOVER, Ada Pellegrini. Teoria Geral do Processo, Malheiros Editores, $22^{a}$ ed. São Paulo, 2006. p. 118.
} 
alicerces da República Federativa do Brasil, sendo o valor social do trabalho explícito como fundamento. Além disso, de acordo com o art. 170 da Constituição Federal, a ordem econômica é "fundada na valorização do trabalho humano" e, conforme o disposto no art. 193, "a ordem social tem como base o primado do trabalho" 4 . Deste modo, o trabalho humano possui status constitucional, de ampla dimensão, devendo estar harmonizado com o princípio da dignidade humana, pois o trabalhador, de acordo com esses preceitos legais, tem direito a uma vida digna, com um trabalho que lhe traga ao menos o mínimo de subsistência ${ }^{5}$. Conclui-se, portanto, que os direitos sociais e individuais são a essência e o principal objetivo de todo o trabalho do Estado Democrático de Direito ${ }^{6}$.

Nesse contexto, os seres humanos não podem ser tratados como meros objetos, mas sim como sujeitos, em que se extrapolam as suas individualidades, considerando-os um espectro comunitário social, cujo trabalho os dignifica na medida em que permite a sua participação de forma integral na vida social e a sua afirmação dentro de sua família. Seguindo tais princípios e fundamentos estipulados, o Processo do Trabalho deve se apoiar claramente no valor social do trabalho humano, sendo um instrumento eficaz para que as pessoas tenham um trabalho digno e que lhes seja justo de acordo com o que dispõe a Constituição Federal. Contratos de trabalho ou disposições contrárias a isso não devem prevalecer ao final do procedimento trabalhista, devendo seu julgador, para efetivação do valor social do trabalho, se valer de princípios e normas que se harmonizam com o estado de dignidade do trabalhador.

Um desses princípios mencionados teve seu surgimento de acordo com a preocupação em se amparar a parte mais vulnerável na relação trabalhista. Assim, ao contrário da busca de igualdade presente no Direito Civil, o preceito da proteção ao trabalhador tem o escopo de equilibrar as desigualdades durante o processo, buscando aplicar a igualdade substancial entre as partes, deixando a relação processual mais justa e com iguais condições de ambos os lados. No entanto, não se pode concluir que, existindo

\footnotetext{
${ }^{4}$ STUCHI, Victor Hugo Nazário. A valorização do trabalho humano como forma de realização do ideal de justiça social. Revista Eletrônica Scientia Faer, Olimpia: Faculdade Ernesto Riscali, Ano 2, v. 2, $1^{\circ}$ sem., p. 130-140, 2010. p. 135.

${ }^{5}$ Jornal Trabalhista, São Paulo, Consulex, v. 20, n. 961, p. 12-13, 2003. p. 12.

${ }^{6}$ FINATI, Cláudio Roberto. O valor social do trabalho. Revista do Tribunal Regional do Trabalho da $15^{\text {a }}$ Região, São Paulo: LTr, n. 8, p. 28-39, 1996. p. 28.
} 
tal proteção, o trabalhador será favorecido cegamente em relação ao empregador. Nesse princípio, a palavra essencial não é favorecimento, mas sim paridade. Não há uma busca por aumentar o peso de um lado da balança que antes era mais leve e sim um meio de se mexer até que ambos os lados estejam em igualdade.

Sobre seu método de aplicação, a proteção do trabalhador desdobra-se em três preceitos: a) in dubio pro operario; b) norma mais favorável e c) condição mais benéfica ${ }^{7}$.

Análogo ao in dubio pro reo presente no Direito Penal, bem como o favor debitoris disposto no Direito Civil, a regra do in dubio pro operario visa proteger a parte que se presume mais vulnerável na relação jurídica, sendo por muitas vezes o empregado. Diante disso, deverá ser aplicado de maneira inversa do princípio vigente no direito comum ${ }^{8}$. $\mathrm{O}$ in dubio pro operario permite ao julgador a escolha da interpretação mais favorável ao trabalhador nos casos em que exista um conflito de possíveis interpretações e desde que não se trate de matéria probatória ou de norma que afronte a lei.

Todavia, não serão todos os casos em que se poderá afirmar de forma evidente que o empregado seja a parte mais frágil da relação jurídica. Sendo assim, a aplicação do in dubio pro operario pode ser mitigado nessas ocasiões, já que a hipossuficiência é recíproca. Nestes casos, a subordinação será jurídica ao invés de econômica, em que o julgador deve evitar a proteção de uma das partes, pois no caso, ambas já estariam em igualdade.

Sobre a regra da aplicação da norma mais favorável resume-se que, ocorrendo um confronto entre normas compatíveis com a relação trabalhista, deve prevalecer no caso em concreto, a que seja mais favorável ao trabalhador ${ }^{9}$. Neste sentido, não há de maneira concreta uma hierarquia entre normas no Direito do Trabalho, já que será aplicada a mais favorável ao operário. Da mesma forma preceitua Amauri Mascaro Nascimento:

\footnotetext{
${ }^{7}$ AMARAL, Júlio Ricardo de Paula. Princípio da proteção: limitações à aplicação no direito do trabalho. Disponível em: <http://portal.trt15.jus.br/documents/124965/125408/Rev17Art14.pdf/6fb77bea-ce51-468f-8e09-9201b5b434b4>. Acesso em: 30 junho 2016.

${ }^{8}$ LIMA, Francisco Meton Marques de. Princípios de direito do trabalho na lei e na jurisprudência. LTr, 4 ed., 2015, p. 81.

${ }^{9}$ BOTIJA, Eugenio Pérez apud LIMA, Francisco Meton Marques de. "Princípios de direito do trabalho na lei e na jurisprudência", p. 75.
} 
Ao contrário do direito comum, em nosso direito entre várias normas sobre a mesma matéria, a pirâmide que entre elas se constitui terá no vértice, não a Constituição Federal, ou a lei federal, ou as convenções coletivas, ou o regulamento de empresa, de modo invariável e fixo. O vértice da pirâmide da hierarquia das normas trabalhistas será ocupado pela norma mais favorável ao trabalhador dentre as diferentes em vigor.

Referente a essa segunda regra do princípio da proteção, cabe mencionar por fim que, sobrepondo-se ao interesse da coletividade, a norma mais favorável não poderá afrontar o interesse público, ou seja, a categoria profissional do empregado a que se usará tal preceito ${ }^{10}$.

A última regra, conhecida como "condição mais benéfica", determina a prevalência das condições mais vantajosas para o trabalhador, sejam estas ajustadas no contrato de trabalho ou resultantes do regulamento de empresa, ainda que vigore ou sobrevenha norma jurídica imperativa prescrevendo menor nível de proteção e que com esta não sejam elas incompatíveis $^{11}$. A alteração das normas trabalhistas, em seu sentido lato, não pode ocasionar uma modificação que piore as condições de trabalho do empregado. Tal fundamento tem como base a disposição do art. 444 da CLT, segundo a qual "as relações contratuais de trabalho podem ser objeto de livre estipulação das partes interessadas em tudo quanto não contravenha às disposições de proteção ao trabalho, aos contratos coletivos que lhes sejam aplicáveis e às decisões das autoridades competentes.

Entretanto, não existe condição mais benéfica que decorra de condições de trabalho adversas, mesmo tais situações gerando uma remuneração maior ao operário. Sendo assim, um empregado que receba os adicionais de insalubridade, periculosidade ou noturno, além dos que tem direito às horas extras, não deverá recebê-los caso ocorra a eliminação da insalubridade, periculosidade, trabalho noturno e extraordinário, com a consequente exclusão do pagamento. Isto pelo simples fato de não se tratar de caso de supressão de condição mais benéfica ao empregado.

${ }^{10}$ LIMA, Francisco Meton Marques de. Princípios de direito do trabalho na lei e na jurisprudência. LTr, 4 ed. , 2015, p. 76.

${ }^{11}$ SÜSSEKIND, Arnaldo; MARANHÃO, Délio; VIANNA, Segadas; TEIXEIRA FILHO, João de Lima. Instituições de direito do trabalho, p. 134. 
Encerrando a discussão sobre alguns dos preceitos essenciais do processo trabalhista, o princípio inquisitivo confere ao juiz a função de impulsionar o processo (por isto, também é conhecido como "impulso oficial") na busca de dizer o direito presente no conflito de interesses de determinada relação jurídica. Conforme o art. $2^{\circ}$ do Novo CPC, "o processo civil começa por iniciativa da parte, mas se desenvolve por impulso oficial."

Tendo em vista que o julgador não pode de ofício iniciar um processo, apenas após a manifestação do interesse da parte autora, através da petição inicial e sua distribuição, torna-se dever do juiz dar impulso ao feito, tomando todas as medidas necessárias ao desenvolvimento do processo.

Contudo, o Processo do Trabalho possui uma peculiaridade em relação ao princípio inquisitivo. Tal característica está presente nos processos executórios trabalhistas, em que há a possibilidade do juiz promover a execução ex officio ${ }^{12}$, conforme dispõe o art. 878, caput, da CLT: “A execução poderá ser promovida por qualquer interessado, ou ex officio pelo próprio Juiz ou Presidente ou Tribunal competente, nos termos do artigo anterior". Baseado nisto, é vedado ao juiz trabalhista a decisão que ordene o arquivamento dos processos com fundamento no art. $2^{\circ}$ do Novo Código de Processo Civil nos casos em que a fase de conhecimento e liquidação já se solidificaram.

\section{APLICAÇÃO SUPLETIVA E SUBSIDIÁRIA}

Assim como ocorre em qualquer ciência, o ser humano opta por criar divisões entre os ramos do Direito. Na tentativa de separar o "joio do trigo", os estudiosos estabeleceram as matérias de acordo com o bem jurídico a ser tutelado, além da essência de certa relação jurídica. Para o Direito Penal, em síntese, a tutela está na proteção de direitos infringidos por uma conduta típica, antijurídica e culpável. No ramo trabalhista, a proteção se faz sobre a parte mais vulnerável da relação de trabalho, o empregado, sendo que as normas da CLT e da Constituição Federal se esforçam para lhe trazer um mínimo de dignidade, sem falar na busca pela diminuição das

12 FELICIANO, Guilherme Guimarães, Revista do Tribunal Regional do Trabalho da 15 ${ }^{\text {a }}$ Região, n. 43, 2013. 
desigualdades existentes no âmbito socioeconômico. Já na esfera cível, o foco está em regular o conjunto de direitos e obrigações de ordem privada concernente às pessoas, aos seus direitos e obrigações, aos bens e às suas relações, enquanto membros da sociedade.

Contudo, para tornar efetivo determinado direito material, se faz necessária a existência de um caminho, um meio justo e eficaz para se chegar a real tutela desse direito. Eis a importância do processo para eficiência da justiça. Sendo de maneira mais econômica e acessível, mas ao mesmo tempo hábil para que se evite um dano irreparável, o processo é um instrumento que torna "tangível" as belas palavras presentes em uma norma. Com base nisto, tal procedimento nunca será imutável, devendo trilhar pelo caminho mais efetivo possível. Evoluir para melhor. Isto deve ser o primeiro pensamento para quem elabora e para quem interpreta as leis.

$\mathrm{Na}$ tentativa de apresentar a importância de um procedimento adequado para determinado ramo do Direito, será analisada a evolução do Processo do Trabalho e do Processo Civil, passando para uma minuciosa comparação entre ambos os instrumentos, demonstrando assim o quão próximo estariam um do outro.

Antes da Constituição de 1934, cabia aos estados brasileiros legislar sobre o processo civil. Para o Ministro da Justiça, Francisco de Campos, tal medida era uma "desastrosa tendência a descentralização" 13 . Todavia, na década de 30, com a força da política centralizadora de Getúlio Vargas, o contexto do Brasil passou a exigir a criação de um processo civil centralizado, que regularia todo o país, cabendo à União a competência exclusiva para legislar sobre a matéria. Nesse mesmo contexto histórico, Getúlio passa a criar órgãos capazes de regular algumas relações de trabalho como o Ministério do Trabalho e as Juntas de Conciliação e Julgamento, sendo que todos os órgãos pertenciam ao Poder Executivo, o que demonstrava sua natureza administrativa. A princípio, devia-se buscar a conciliação para solução dos conflitos trabalhistas. Não sendo possível a solução, partia-se para a arbitragem, e em casos negativos, o Estado se retirava do conflito caso não fosse essencial. Assim, ao passo que o Processo Civil evoluía para uma nova fase de centralização, mas pertencendo ao Judiciário, as normas trabalhistas possuíam cunho administrativo, estando ligadas ao Poder Executivo.

${ }^{13}$ CAMPOS, Francisco. A reforma do processo civil. Revista Forense. Rio de Janeiro: Forense. 1939, p.187. 
No final da década de 30, a pressão social que reclamava por um instrumento mais eficiente e próximo do povo se fortaleceu. O novo regime deveria constituir a restauração da autoridade e do caráter popular do Estado, de modo que a opção política do Código era uma consequência necessária do regime instaurado em 10 de Novembro e definido na Constituição. Procurava-se, ainda nas palavras do Ministro Francisco Campos, "aproximar, o mais possível, Governo e Povo", eliminando-se os intermediários na vida política do Brasil. Desta forma, o Código de Processo Civil "exprimiria, no campo em geral tão impermeável do sistema legal, essa tendência vital do regime, entregando ao povo um instrumento fácil e direto para fazer valer os direitos" que a lei civil lhe atribuía ${ }^{14}$. O Processo do Trabalho, por sua vez, se fortalecia com a criação da Justiça do Trabalho em 1939, ainda com laços do Poder Executivo. Instalada em $1^{\circ}$ de Maio de 1941, tal Justiça contava com três instâncias: o Conselho Nacional do Trabalho (CNT), a Junta de Conciliação e Julgamento (JCJ) e o Conselho Regional do Trabalho (CRT). Poucos anos depois, em 1943, surge a CLT englobando assunto processual e material. Com o passar do tempo, a Justiça do Trabalho alcançaria seu caráter judicial, compondo o Poder Judiciário com três instâncias: a JCJ, o Tribunal Regional do Trabalho (TRT) e o Tribunal Superior do Trabalho (TST), tendo vogal em todas as instâncias.

Passando para os anos seguintes, em 1969 surge o Decreto-Lei 779, que disciplinaria a atuação da Fazenda Pública na Justiça do Trabalho. Um ano depois, é criada lei 5.584/70, a qual regularia o procedimento sumário, sendo este das causas com até dois salários mínimos. A referida lei também previa a assistência judiciária prestada pela entidade sindical. Quanto ao procedimento civil, um novo código fora criado em 1973 com origem no anteprojeto apresentado em 1964 pelo então Ministro da Justiça Alfredo Buzaid. Conhecidos como os "anos de chumbo" do Brasil, a década de 60 marcou a história do país graças às suas medidas autoritárias, como o fechamento do Congresso, a autorização do Executivo para legislar, a suspensão de garantias constitucionais e legais como vitaliciedade, inamovibilidade ou estabilidade dos juízes, a permissão para o presidente demitir, remover, aposentar, transferir juízes, empregados e militares e a suspensão das imunidades parlamentares. Diferente do Código de 1939, que apostava no caráter público e social do processo, o Código Buzaid era

${ }^{14}$ CAMPOS, Francisco. A reforma do processo civil. Revista Forense. Rio de Janeiro: Forense. 1939, p.189. 
um Código focado na técnica e na neutralidade científica, em suma, na indiferença social que bem se amoldava aos valores liberais que encamparam a teoria do processo como relação jurídica, perspectiva própria de um projeto histórico de neutralidade social ${ }^{15}$.

Como se pode notar, ambos os procedimentos analisados passaram por estágios e reformulações, estando presentes em vários períodos históricos do País. Entretanto, há diferenças que devem ser mencionadas. No âmbito trabalhista, a luta que enseja sua evolução até os dias de hoje está no anseio do trabalhador em obter sua dignidade ferida pelos abusos e desigualdades econômicas. Assim, por mais que tivesse a princípio um elo com o Poder Executivo e regulasse apenas algumas classes de trabalhadores urbanos, as normas de Direito Material e Processual trabalhistas tendem a evoluir de maneira a propiciar uma melhor condição ao proletariado. Sua presença no Poder Judiciário, além de mais correta no sentido técnico, também torna mais efetiva a tutela do Direito. O procedimento Civil, por sua vez, regula direitos entre pessoas de mesmo patamar social, usando-se de regras de cunho liberalista. Neste instrumento não há uma parte que está subordinada à outra, nem mesmo, via de regra, a presença de autotutela como possui o empregador nos dias de trabalho. Sendo assim, aqueles que procuram relacionar ambos os ramos jurídicos devem ter cautela na análise, ainda mais quando se tem a presença de dois artigos polêmicos (art. 769 CLT e 15 do novo CPC) que apresentam possibilidades de relacionamento entre Processo do Trabalho e Processo Civil.

Encerrado o levantamento histórico dos procedimentos trabalhista e cível, a etapa seguinte está em esclarecer as interpretações obscuras que permeiam o âmbito jurídico quando se trata da tentativa de relacionar os dois processos. Deste modo, o Processo do Trabalho merece ser destrinchado em suas características e preceitos próprios, sendo utilizados métodos de interpretação já citados anteriormente, como a integração de lacunas e a colisão entre normas e princípios.

O Direito do Trabalho, diferente do ramo jurídico cível, tem característica de Direito Social, isto é, um método para que se objetive a elaboração de coerções suficientes para impor limitações necessárias aos abusos do capitalismo, diminuindo as injustiças sociais existentes. Para Jorge Luiz Souto Maior, "a construção teórica do Direito Social, ademais, é o que confere a possibilidade de se estabelecerem diretrizes metodológicas

${ }^{15}$ CARVALHO, Orlando de. A teoria geral da relação jurídica - Seu sentido e limites. Coimbra: Centelha, 1981, p. 35. 
para uma problematização da realidade a partir das aflições alheias, permitindo visualizar a solução jurídica necessária à preservação e elevação da condição humana" ${ }^{16}$. De acordo com o jurista mencionado, não reconhecendo tal característica social do Direito do Trabalho, a consequência será uma conciliação de valores inconciliáveis, sendo que muitos deles já estão superados.

Influenciado por essa interpretação é que surge o pensamento de que o Direito se divide em Público e Privado, sendo que o último seria uma possibilidade para se usufruir dos valores liberais sem muitos limites. No entanto, ambas as divisões não atendem ao conceito de Direito Social. O campo do Direito Privado (o Direito Civil, por exemplo) apoia-se na ideia de que as partes da relação jurídica estão em igualdade, devendo as regras de o contrato realizado ser obedecidas. Ultimamente é perceptível algum tipo de mudança nesse quesito, buscando os doutrinadores civilistas uma constitucionalização da matéria para que alguns direitos presentes na Carta Magna sejam preservados. Algo um pouco estranho, já que isso não deveria ser matéria de debate, mas sim um conceito primordial desde o começo. Mesmo assim, a evolução é válida. Quanto ao Direito Público, sua relação unicamente entre Estado e um sujeito de direito não atende ao conceito de Direito Social.

Não havendo nos dois campos mencionados as características necessárias para a compatibilidade com o Direito Social, o qual é a essência do Direito do Trabalho, o ramo jurídico trabalhista ficaria por fora das duas divisões. Contudo, há quem acredite que o Direito do Trabalho é um apêndice do Direito Civil, ou que tenha nascido do Direito Civil e que, agora, diante das evoluções tecnológicas, estaria voltando à sua raiz ${ }^{17}$. Ledo engano. As regras de proteção aos trabalhadores surgiram para conter o capitalismo desenfreado durante o Estado Liberal, transformando-o, assim, em Estado Social. Mesmo tal mudança da compreensão jurídica não sendo capaz de alterar de maneira considerável a liberdade ilimitada dos negócios no âmbito cível, não há como negar a emergência dos direitos sociais, proporcionando novas áreas do Direito, como o Direito do Trabalho e o Direito

\footnotetext{
${ }^{16}$ SOUTO MAIOR, Jorge Luiz. Relação entre o Processo Civil e o Processo do Trabalho. O Novo Código de Processo Civil e sua Aplicação ao Processo do Trabalho. JusPODVM. Salvador-BA, p. 160.

${ }^{17}$ SOUTO MAIOR, Jorge Luiz. Relação entre o Processo Civil e o Processo do Trabalho. O Novo Código de Processo Civil e sua Aplicação ao Processo do Trabalho. JusPODVM. Salvador-BA, p.161.
} 
Previdenciário, ramos que integrariam uma terceira divisão do Direito, o Direito Social.

Todavia, grandes erros foram ocasionados pela falsa ideia de que o Direito Trabalhista seria uma espécie, um ramo do Direito Civil. Para Souto Maior:

O mais grave foi integrar os estudos do processo do trabalho à linha dos estudos do processo civil. Ora, o processo é instrumento de efetivação do direito material. E se o direito material ao qual o processo civil está voltado é o direito civil, com uma lógica pretensamente liberal, é óbvio que o processo civil reflete esse sentimento.

Com base nisso, as normas processuais civis, sob a ótica do disposto no art. 769 da CLT, devem ser utilizadas apenas com o intuito de complementação para as finalidades do processo do trabalho, tendo em vista que este busca ser um instrumento prático e eficiente para se fazer valer os direitos desrespeitados pelo empregador. O procedimento trabalhista tem como uma das partes alguém que necessita da tutela jurisdicional para sobreviver. O salário é um direito constitucional, assim como a vida. Sem ter como sustentar a si e a sua família, o empregado perde sua dignidade humana. Deste modo, a Justiça do Trabalho preza, de maneira correta, por um processo rápido e justo.

Mesmo com a criação do art. 15 do Novo Código de Processo Civil, a interpretação não pode ser distinta. Isto porque o referido artigo é explícito em dizer que a aplicação das normas de processo civil serão aplicadas supletiva e subsidiariamente. $\mathrm{O}$ art. 15 do Novo CPC, ao contrário do que alguns acreditam, não revogará o presente no art. 769 da CLT. Primeiramente pelo fato de que são processos de direitos materiais distintos, não podendo uma norma de cunho civil revogar matéria trabalhista. Sem contar que ambas as normas não estão em conflito, mas servem de reforço para o pensamento ideal: utilizar como regra a CLT para depois, inexistindo incompatibilidade, aplicar normas processuais civis.

Obviamente, as normas do procedimento cível que auxiliarem em tais preceitos trabalhistas devem ser utilizadas. Isto porque a própria CLT permite a hipótese em seu art. 769. Ainda assim, a aplicação deve estar 
condicionada aos fatores de omissão e compatibilidade (intuito de suplementação) com as normas trabalhistas. O apelo que deve ser feito é de que o Processo do Trabalho deve ter como norte os princípios do Direito do Trabalho, sendo esta uma conclusão de uma simples regra: o processo se guia pelo direito material a que se está relacionado e que se busca tutelar. Utilizando mais uma vez das palavras de Jorge Luiz Souto Maior:

Ora, se o Direito do Trabalho é protetivo para conferir eficácia aos direitos e se os direitos trabalhistas, quando resistidos pelo empregador, só se tornam efetivos pela via processual, é mais evidente que esta via, a do processo, deve se guiar pelos mesmos princípios extraídos da racionalidade protetiva, pois do contrário seria o mesmo que negar aos direitos trabalhistas a possibilidade de realização concreta.

Usa-se assim, das disposições de colisão de normas e princípios e integração de lacunas. Apenas na inexistência de norma trabalhista é que se deve buscar o preenchimento nas disposições do processo civil. Além disso, tal integração deve estar coerente com os princípios do Direito do Trabalho, tendo em vista a colisão entre preceitos de caráter primordial (como a vida, dignidade etc) e princípios secundários como a liberdade de contratar (lembrando, que havendo conflito entre norma e princípio devese encontrar o preceito que motivou a regra, para então fazer um sopesamento entre princípios e não entre este e uma norma).

Por fim, vale a ressalva de que o Direito do Trabalho não pode ser classificado como um direito individual, pois o descumprimento de uma norma trabalhista, ainda que afete de início apenas os envolvidos, desestabiliza toda a classe social em prol da economia. Deste modo, as normas trabalhistas assumiriam a caracterização de Direito Social, tendo em vista que não seguem os valores liberais do Direito Privado e nem estão vinculadas às relações jurídicas com o Estado como sujeito de direito, não pertencendo também ao Direito Público. Como Direito Social, o Direito do Trabalho objetiva a formulação das coerções eficientes para impor limites necessários às relações capitalistas, visualizando a superação das injustiças 
sociais geradas ${ }^{18}$. Desrespeitar um direito de um trabalhador significa, portanto, abrir a possibilidade da mesma infração com os demais. Desta maneira, o disposto presente nos arts. 769 da CLT e 15 do Novo CPC deve ser analisado como regras para proteger a CLT, freando abusos de interpretações equivocadas e que de nada contribuirão com o andamento do processo, mas apenas o deixarão mais ineficiente e moroso.

\section{O INCIDENTE DE DESCONSIDERAÇÃO DA PERSONALIDADE JURÍDICA NO PROCESSO CIVIL}

Novidade na nova codificação processual civil, o incidente de desconsideração da personalidade jurídica está previsto no art. 133 e seguintes. Logo no primeiro dispositivo, há a exemplificação de quem terá legitimidade para instaurar o referido incidente:

Art. 133. O incidente de desconsideração da personalidade jurídica será instaurado a pedido da parte ou do Ministério Público, quando lhe couber intervir no processo.

$\S 1$ o O pedido de desconsideração da personalidade jurídica observará os pressupostos previstos em lei. $\S 20$ Aplica-se o disposto neste Capítulo à hipótese de desconsideração inversa da personalidade jurídica".

Tal pedido para se desconsiderar a personalidade jurídica faz surgir, de imediato, um incidente a ser solucionado pelo juiz da causa antes da apreciação do pedido principal. Contudo, o novo CPC apenas estabeleceu as regras próprias para este incidente, não tratando das situações em que deverá ocorrer a desconsideração da personalidade jurídica. Sendo assim, a análise deste instituto permanece acobertada pelo Código de Defesa do Consumidor, à Lei no 8.884/94, à Lei 9.605/98 e ao Código Civil ${ }^{19}$.

\footnotetext{
${ }^{18}$ MAIOR, Jorge Luiz Souto, Relação entre Processo Civil e Processo do Trabalho. Novo Código de Processo Civil e seus Reflexos no Processo do Trabalho, JusPODVM, Salvador-BA. 2015.

${ }^{19}$ ALMEIDA, Cléber Lúcio de, Incidente de desconsideração da personalidade jurídica. O Novo Código de Processo Civil e sua aplicação ao Processo do Trabalho. JusPODIVM. $2^{\text {a }}$ ed. Salvador-BA. 2015.
} 
Este incidente burocrático criado pelo legislador tem recebido aplausos por parte da doutrina do processo civil, tendo em vista que proporcionará o contraditório pleno no exame da questão, bem como evitará os chamados abusos judiciais na desconsideração de ofício, com a penhora dos bens de sócios que já não faziam mais parte da sociedade ou que não a administravam, proporcionando-lhes a ampla defesa antes de ver seu patrimônio constrito ${ }^{20}$. Deste modo, no procedimento comum, o incidente de desconsideração da personalidade jurídica foi um instituto digno de elogios, que cumprirá com princípios constitucionais se aplicados de maneira correta e sem o intuito de prolongar o processo de maneira desnecessária.

Prosseguindo, em seu art. 134 o novo Código de Processo Civil demonstra que "é cabível o incidente de desconsideração da personalidade jurídica em todas as fases do processo de conhecimento, no cumprimento de sentença e na execução fundada em título executivo extrajudicial". Com este dispositivo, o novo CPC afasta a tese segundo a qual somente na execução, após constatada a incapacidade de o devedor responder por seus débitos, é que pode ser pleiteada a desconsideração da personalidade jurídica. Já em seu parágrafo $2^{\circ}$, o artigo mencionado trata de uma situação de dispensa da instauração do incidente, sendo esta a hipótese de requerimento da desconsideração logo na petição inicial, quando será citado o sócio ou a pessoa jurídica. Esta citação, por óbvio, torna o sócio parte da demanda, sendo dispensada a desconsideração por seu objetivo já estar sendo cumprido, isto é, atingir o patrimônio do sócio.

Para alguns doutrinadores ${ }^{21}$, o $\$ 2^{\circ}$ do Novo CPC trata-se de uma hipótese esdrúxula, já que, nessa circunstância, o que verdadeiramente ocorre é a formação de um litisconsórcio passivo facultativo, desde o início, e não uma forma de intervenção de terceiros.

Quanto a esse parágrafo, ainda é imprescindível o comentário de que o mesmo deva ser aplicado na hipótese de desconsideração inversa da personalidade jurídica, sendo esta a imputação da pessoa jurídica pelas obrigações contraídas pelo sócio individualmente, tendo como pressuposto a existência do desvio de bens de uma pessoa física para uma pessoa jurídica, sobre a qual aquela contém o controle ${ }^{22}$.

\footnotetext{
${ }^{20}$ SILVA, José Antônio Ribeiro de Oliveira. Comentários ao Novo CPC e sua Aplicação ao Processo do Trabalho. LTr 80, São Paulo, 2016, p. 192.

${ }^{21}$ Vide José Antônio Ribeiro de Oliveira Silva.

22 JÚNIOR, Nelson Neri. Comentários ao novo Código de Processo Civil. 1 ed. Rio de Janeiro: Forense. 2015. p. 572.
} 
Adiante, no parágrafo $3^{\circ}$ do art. 134 revela que o incidente de desconsideração da personalidade jurídica suspenderá o curso do processo, sendo desnecessária a ressalva constante da parte final do $\S 2^{\circ}$, vez que, se não foi instaurado o incidente, não há que se falar na suspensão do processo relacionado ${ }^{23}$.

Pelo fato da desconsideração da personalidade jurídica vincular o patrimônio do sócio ou da pessoa jurídica ao cumprimento obrigacional destes, respectivamente, não pode ser negada a oportunidade de o sócio ou a pessoa jurídica se manifestarem e produzirem provas de suas alegações em obediência ao contraditório e ao devido processo legal. Por conseguinte, o fato de o procedimento civil prever a citação do sócio ou pessoa jurídica para se defender em 15 dias, demonstra ser uma norma acertada do legislador nas hipóteses/relações existentes no âmbito civil. Isto porque aqui, via de regra, a relação parte do pressuposto de partes em mesmo patamar, sem existência do caráter de hipossuficiência ou subordinação (diferente do que ocorre nas relações de consumo e trabalhistas).

Para a comprovação dos fatos alegados pela parte que requisitou a desconsideração da personalidade jurídica podem ser utilizados todos os meios permitidos por lei, bem como os moralmente legítimos, mesmo que não especificados por lei (inteligência esta do art. 332 do Código de Processo Civil em vigor). Uma vez instaurado o incidente, e havendo necessidade de produção de prova oral, deverá ocorrer a designação de audiência para este fim. No caso de pedido de desconsideração apresentado juntamente à petição inicial, a prova dos fatos a ele relacionados deverá ser produzida em conjunto com a prova dos fatos do pedido principal ${ }^{24}$.

Sobre o caráter decisório do incidente, o art. 136 dispõe:

“Art. 136. Concluída a instrução, se necessária, o incidente será resolvido por decisão interlocutória.

Parágrafo único. Se a decisão for proferida pelo relator, cabe agravo interno".

\footnotetext{
${ }^{23}$ ALMEIDA, Cléber Lúcio de, Incidente de desconsideração da personalidade jurídica. O Novo Código de Processo Civil e sua aplicação ao Processo do Trabalho. JusPODIVM. 2a ed. Salvador-BA. 2015.

${ }^{24} \mathrm{Ib}$ idem.
} 
Nessas circunstâncias, no momento que a apresentação do pedido de desconsideração ocorrer com a petição inicial e do seu exame decorrer uma sentença, contra esta poderá ser apresentada apelação. De maneira contrária, ocorrido o incidente no decorrer do processo, a decisão sobre o pedido de desconsideração será interlocutória, o que a torna passível de agravo de instrumento (se em $1^{\mathrm{a}}$ instância) ou interno (se em grau de recurso). Além do mais, havendo requerimento de provas pelo sócio ou pela pessoa jurídica, o juiz as permitirá, caso seja necessária, designando audiência de instrução.

Finalizando a análise do incidente de desconsideração da personalidade jurídica, o art. 137 do Novo Código de Processo Civil prevê que, "acolhido o pedido de desconsideração, a alienação ou oneração de bens, havida em fraude de execução, será ineficaz em relação ao requerente". Vale ressaltar que mesmo a pessoa jurídica ou o sócio sendo parte passiva de uma ação, este fato não o impede de alienar bens de sua propriedade. Isto, é claro, se a alienação não proporcionar riscos para seus credores. Ciente disto, o legislador estabeleceu condições para que a transferência da propriedade dos bens da pessoa jurídica ou do sócio não serão eficazes contra o credor.

Iniciando a análise crítica sobre esta inovação incidental no Novo CPC, José Antônio Ribeiro de Oliveira Silva expõe seu ponto de vista ao dizer:

Sem embargo, parece-nos que, na prática, o resultado será nefasto. Se a preocupação era com o sócio retirante, por que esse procedimento burocrático não foi reservado para essa situação, de retirada do sócio bem antes da desconsideração da personalidade jurídica? Em regra, quando o juiz toma essa medida, ele tem todas as alterações societárias da sociedade, inclusive porque as pesquisas feitas mediante convênios celebrados the permitem acesso a toda a documentação. Seria, portanto, mais salutar que esse procedimento fosse reservado para os casos em que se busque atingir sócios que não mais figuram no contrato social. 
Ademais, é evidente que a execução, seja em qualquer ramo do Direito, preza pela celeridade e efetividade, de modo que se conclua a prestação jurisdicional e se realize a verdadeira justiça. De nada adiantaria a confiança em uma decisão harmonizada com o trânsito em julgado, se na fase de sua efetivação houvesse demora em prol da parte executada, que teve sua chance de defesa. Quanto ao incidente, este merece elogios em uma aplicação legal de seus preceitos em âmbito civil, pelos fatos expostos acima. Em relação à seara trabalhista, de plano se percebe um desrespeito às regras de hermenêutica. Os regramentos acerca do incidente revelam uma ligação com os princípios do contraditório e ampla defesa que devem sim serem respeitados. Contudo, do outro lado existe, no processo do trabalho, a existência de uma parte que se submete às normas de um empresário (o qual explora seu trabalho e detém a responsabilidade pelos riscos do empreendimento), sujeitando-se, por muitas vezes, a condições precárias em busca do sustento de sua família.

Nem todos têm as oportunidades de atingirem altos patamares financeiros. Independente dos fatores e ideologias é fato a relação de subordinação do empregado quanto ao seu empregador, com grandes diferenças financeiras entre ambos. Deste modo, a justiça, buscando honrar este nome, não deve criar meios para proteger uma parte que, além de estar em condição de superioridade, também não logrou êxito em sua defesa na fase de conhecimento. Ainda que de maneira indireta, no caso de uma sociedade, o risco da atividade econômica pertence ao empregador, pois, se não o fosse, não poderia obter lucro desta. E o fazendo, também deve arcar com suas responsabilidades, ainda mais existindo um crédito de natureza alimentar somada a uma decisão transitada em julgado.

\section{$4 \quad$ INCOMPATIBILIDADES COM O PROCESSO DO TRABALHO}

A questão do incidente de desconsideração da personalidade jurídica demonstra aspectos que devem ser interpretados com cautela. Seguindo o disposto em tal teoria, ainda que distintas a pessoa dos sócios com a pessoa jurídica, em certas hipóteses haverá a autorização para se desconsiderar a distinção, visando que os patrimônios dos sócios respondam por obrigações da pessoa jurídica. Tal fenômeno se apresenta como uma exceção pelo fato de que a pessoa jurídica é dotada de personalidade jurídica, 
podendo exercer direitos e obrigações. Vigora, no caso em questão, o princípio da autonomia patrimonial entre pessoa jurídica e os sócios que a compõem.

Sabendo disto, desconsiderar a personalidade jurídica significa relativizar a autonomia inerente à pessoa jurídica. Com efeito, desconsiderada a autonomia patrimonial da pessoa jurídica, os seus sócios passam a responder pelas suas dívidas, observando-se que a desconsideração da personalidade jurídica não resulta na negativa definitiva da autonomia patrimonial da pessoa jurídica, mas no afastamento em relação à determinada obrigação $^{25}$.

Resumindo o já disposto em tópico anterior, de acordo com o art. 134 do novo CPC, o incidente de desconsideração pode ser utilizado em qualquer fase do processo de conhecimento, no cumprimento de sentença e na execução fundada em título executivo extrajudicial. Nos demais artigos seguintes, os quais também tratam sobre o tema, vale citar o art.137, no qual "acolhido o pedido de desconsideração, a alienação ou oneração de bens, havida em fraude de execução, será ineficaz em relação ao requerente". Deste modo, o legislador estabelece situações em que a alienação ou oneração de bens pelos sócios ou pela pessoa jurídica não terá eficácia contra o credor. Da mesma forma que o código permite a defesa do sócio quando instaurado o incidente ${ }^{26}$, respeitando-se o contraditório e a ampla defesa, também se evita a ocorrência de fraudes no percurso da execução.

A dúvida que parece se difundir cada vez mais nas discussões jurídicas sobre o incidente de desconsideração da personalidade jurídica é a da aplicabilidade de suas disposições durante a execução trabalhista. Como já se discorreu por diversas vezes durante o presente trabalho, a aplicação das normas do novo Código de Processo Civil só deve existir na ocorrência de omissão ou necessidade de suplementação, além de ser obrigatória a harmonia dos dispositivos processuais civis com os preceitos e normas trabalhistas. No campo da execução, a prioridade de aplicação de legislação processual subsidiária está na lei dos executivos fiscais (Lei $\mathrm{n}^{\circ}$ 6830/80), com exceção a observância da ordem legal de preferência de

\footnotetext{
${ }^{25}$ ALMEIDA, Cléber Lúcio de, Incidente de desconsideração da personalidade jurídica. O Novo Código de Processo Civil e sua aplicação ao Processo do Trabalho. JusPODIVM. $2^{\mathrm{a}}$ ed. Salvador-BA. 2015.

${ }^{26}$ Art. 135. "Instaurado o incidente, o sócio ou a pessoa jurídica será citado para manifestarse e requerer as provas cabíveis no prazo de 15 (quinze) dias".
} 
bens à penhora presente no art. 655 do CPC e do art. 882 da CLT ${ }^{27}$. Além disso, a referida lei demonstra de maneira evidente que a execução fiscal poderá ser redirecionada para os sócios, bastando que os bens do devedor sejam capazes de satisfazer a dívida ${ }^{28}$.

Ciente de tais fatos, como a norma aplicável nos dias de hoje permite que se redirecione a execução para os sócios, sendo como única condição para tanto a insuficiência de bens da pessoa jurídica, e pelo fato da execução trabalhista tramitar de ofício, não há motivos plausíveis para se aguardar o requerimento da parte ou do Ministério Público ${ }^{29}$ e para se motivar a realização da desconsideração. Sobre a matéria de defesa do sócio na existência da desconsideração, basta apenas que este indique o patrimônio da pessoa jurídica capaz de atender à execução trabalhista. Isto pelo fato de que a dívida trabalhista por parte do sócio é presumida desde a propositura da ação trabalhista, não ferindo o contraditório e a ampla defesa, sem contar que a única matéria a ser alegada seria a de existência do patrimônio da pessoa jurídica sobre o qual pode recair a execução no Processo do Trabalho, tendo em vista que a inexistência de patrimônio seria o único pressuposto para a desconsideração.

Destarte, de plano já se deve expor a inaplicabilidade do art. 136 da nova codificação processual civil, tendo em vista que a decisão interlocutória, se proferida em primeira instância, seria irrecorrível de imediato no processo do trabalho ${ }^{30}$.

Além do mais, deve-se ter em mente que o processo do trabalho não permite qualquer regalia para o devedor no trâmite de uma execução. Existindo o débito, o devedor deve cumprir sua obrigação, pois esta possui caráter alimentar e de subsistência ao trabalhador. Sendo assim, é nítido que o instituto do incidente da desconsideração da personalidade jurídica

\footnotetext{
${ }^{27}$ NOGUEIRA, Eliana dos Santos Alves, Incidente de desconsideração da personalidade jurídica. O Novo Código de Processo Civil e sua aplicação ao Processo do Trabalho. JusPODIVM. $2^{\mathrm{a}}$ ed. Salvador-BA. 2015.

${ }^{28}$ Art. $4^{\circ}, \S 3^{\circ}$ da Lei $6830 / 80$. “Os responsáveis, inclusive as pessoas indicadas no $\S 1^{\circ}$ deste artigo, poderão nomear bens livres e desembaraçados do devedor, tantos quantos bastem para pagar a dívida. Os bens dos responsáveis ficarão, porém, sujeitos à execução, se os do devedor forem insuficientes à satisfação da dívida".

${ }^{29}$ Art. 133, caput. "O incidente de desconsideração da personalidade jurídica será instaurado a pedido da parte ou do Ministério Público, quando lhe couber intervir no processo".

${ }^{30}$ Art. 893, $\S 1^{\circ}$, da CLT.
} 
serviria apenas para se retardar o curso do processo, ferindo um dos princípios mais resguardados do Processo do Trabalho, a celeridade. Não se pode comparar uma execução de cunho civil, em que houve uma paridade entre as partes em um processo de conhecimento anterior, com um procedimento que necessita de meios para equilibrar as partes que estão em pé de desigualdade. O incidente de desconsideração da personalidade jurídica fere não só a razoável duração do processo (que deve ser analisado sob uma óptica mais severa quando se trata de matéria trabalhista) como também o princípio da proteção, tornando tardia a efetivação dos direitos do trabalhador, além de descumprir as normas mais favoráveis, que são no caso as de Direito Processual Trabalhista.

Um dos críticos da aplicação do incidente da desconsideração da personalidade jurídica, José Antônio Ribeiro de Oliveira Silva elenca um rol de motivações para tanto:

[...] no processo do trabalho não se exige a demonstração inequívoca dos pressupostos previsto em lei, como os do art. 50 do Código Civil, porque podem ser utilizados os do art. 28 e $\S \S$ do CDC, além do que a jurisprudência trabalhista está solidificada no sentido de que basta a insolvência da sociedade devedora para que se promova a desconsideração da sua personalidade jurídica, tendo em vista que todos os sócios que participaram da sociedade ao tempo da constituição da obrigação trabalhista por ela respondem, por se trata da satisfação de crédito de natureza alimentar [...] no processo do trabalho predomina o princípio aquisitivo - que assim se torna um princípio específico e que dá identidade a este ramo processual -, não somente com fulcro no art. 765 da CLT, mas nesse caso, com fundamento no art. 878 da Consolidação, segundo o qual o juiz do trabalho ou o tribunal pode iniciar a própria execução (ou cumprimento de sentença) de ofício.

Ora, é regra secular de hermenêutica a de que ' quem pode o mais, pode o menos'. Com efeito, se o juiz do trabalho pode dar início à própria execução de ofício, pode determinar, de ofício, a desconsideração da personalidade jurídica, ao verificar a insolvência da sociedade devedora; e o fará para a satisfação do crédito alimentar trabalhista, inclusive porque a 
responsabilidade do sócio é ope legis, restando escancara no art. 795 e $\S \S$ do novo Código de Processo Civil, correspondentes ao art. 596 e $\S \S$ do CPC/1973.

A jurisprudência trabalhista não pode defender a tese de compatibilidade do incidente com o procedimento do trabalho, pois se o fizer os reclamantes passarão a agir com o intuito de contornar uma possível demora no processo, inserindo no polo passivo da demanda todos os sócios, acarretando uma prestação jurisdicional atrasada, tendo em vista as várias citações e um óbvio entrave do processo. Será, sem dúvidas, um caminho contrário ao que defendem o devido processo legal e a celeridade.

O campo legal trabalhista, de maneira clara, cumpre a função clássica de qualquer segmento jurídico: regular condutas, estruturar a convivência social etc. No entanto, o ramo jurídico do Trabalho expressa uma enorme inovação nas concepções do Direito, uma vez que o Direito do Trabalho incorpora e exprime as perspectivas e interesses de camadas sociais tradicionalmente vazias de riqueza e poder.

Como bem discorre Maurício Godinho Delgado ${ }^{31}$ :

O novo segmento jurídico (Direito do Trabalho) despontou a partir da segunda metade do século XIX, como notável instrumento de restrição do poder empresarial no plano da contratação e gestão trabalhistas, elevando, por meio de norma jurídica imperativa, as condições de inserção da força de trabalho no capitalismo.

O Direito do Trabalho, tornou-se na História do Capitalismo Ocidental, um dos instrumentos mais importantes para inserir parte significativa das camadas sociais despossuídas de riqueza material na sociedade econômica. Deste modo, esse instituto adquiriu um caráter de mecanismo basilar de controle e atenuação das distorções socioeconômicas inevitáveis do sistema capitalista. Sem tal ramo jurídico, existiria uma Democracia

${ }^{31}$ DELGADO, Maurício Godinho. Funções do Direito do Trabalho no Capitalismo e na Democracia. Estudos aprofundados da magistratura do trabalho. JusPODIVM. $2^{\mathrm{a}}$ ed. Salvador-BA. 2015, p. 124. 
meramente formal, no plano da política e das instituições estatais, em contraponto com o império unilateral do poder privado, no plano da economia e das instituições privadas. Sua função no mundo globalizado de hoje, com a incessante renovação tecnológica que aumenta as desigualdades manifestas do capitalismo, é de extrema importância para evitar crises cíclicas pertencentes ao sistema econômico, sejam elas econômicas ou sociais.

Adiante, cumpre ressaltar que, ao longo dos anos, o ideário liberalista buscou (e ainda busca) argumentos e discursos em direção ao desprestígio do ramo trabalhista, defendendo uma crescente mercantilização do trabalho na sociedade econômica. Contudo, são claros os exemplos da ineficiência prática das medidas mercantilizadoras propostas por este ideário, as quais são responsáveis pelas várias repetições de crises econômicas, além do aumento da exclusão social em vários países submetidos à sua direta influência. Deste modo, as revoluções do Direito do Trabalho devem permanecer constantes, para que sua influência na sociedade seja sempre a de tutela dos segmentos sociais explorados.

De acordo com os ensinamentos Noberto Bobbio:

[...] Em particular, para decidir se uma norma é válida (isto é, como regra jurídica pertencente a um determinado sistema), é necessário com frequiência realizar três operações: 1) averiguar se a autoridade de quem ela emanou tinha o poder legítimo para emanar normas jurídicas, isto é, normas vinculantes naquele determinado ordenamento jurídico; 2) averiguar se não foi ab-rogada, já que uma norma pode ter sido válida, no sentido de que foi emanada de um poder autorizado para isto, mas não quer dizer que ainda o seja, o que acontece quando outra norma sucessiva no tempo a tenha expressamente ab-rogado ou tenha regulado a mesma matéria; 3 ) averiguar se não é incompatível com outras normas do sistema (o que também se chama ab-rogação implícita), particularmente com uma norma hierarquicamente superior (uma lei constitucional é superior a uma lei ordinária em uma Constituição rígida) ou com uma norma posterior, visto que em todo ordenamento jurídico vigora o princípio de que duas normas incompatíveis não podem ser ambas válidas (assim como em um sistema científico duas proposições 
contraditórias não podem ser ambas verdadeiras). $\mathrm{O}$ problema da validade jurídica pressupõe que se tenha respondido à pergunta: o que se entende por direito? Trata-se, querendo adotar uma terminologia familiar entre os jusfilósofos, do problema ontológico do direito. O problema da eficácia de uma norma é o problema de ser ou não seguida pelas pessoas a quem é dirigida (os chamados destinatários da norma jurídica) e, no caso de violação, ser imposta através de meios coercitivos pela autoridade que a evocou. Que uma norma exista como norma jurídica não implica que seja também constantemente seguida. Não é nossa tarefa aqui indagar quais possam ser as razões para que uma norma seja mais ou menos seguida. Limitamo-nos a constatar que há normas que são seguidas universalmente de modo espontâneo (e são as mais eficazes), outras que são seguidas na generalidade dos casos somente quando estão providas de coação, outras, ainda, que não são seguidas apesar da coação, e outras, enfim, que são violadas sem que nem sequer seja aplicada a coação (e são as mais ineficazes). A investigação para averiguar a eficácia ou a ineficácia de uma norma é de caráter histórico-sociológico, se volta para o estudo do comportamento dos membros de um determinado grupo social e se diferencia, seja da investigação tipicamente filosófica em torno da justiça, seja da tipicamente jurídica em torno da validade. Aqui também, para usar a terminologia douta, se bem que em sentido diverso do habitual, pode-se dizer que o problema da eficácia das regras jurídicas é o problema fenomenológico do direito ${ }^{32}$.

Desta maneira, como demonstrado nos apontamentos acima, o incidente tratado não é justo, pois não deve existir no campo trabalhista em prol dos princípios que este apregoa. Nem mesmo será válido nessa seara por confrontar com as regras da Consolidação. Muito menos deverá ser

${ }^{32}$ BOBBIO, Noberto. Teoria da norma jurídica. Traduzido por Fernando Pavan Baptista e Ariani Bueno Sudatti. Câmara Brasileira do Livro, $2^{\mathrm{a}}$ ed. , 2003, p. 45. 
eficaz, devendo a sociedade, principalmente os profissionais do direito, lutarem pela sua não aplicação, tendo em vista não só a credibilidade do Judiciário, mas também a prevenção de impactos na vida dos milhões de trabalhadores.

Ciente dessa necessidade de uma norma justa, válida e eficaz para o campo trabalhista, o caminho a ser trilhado pelos profissionais do Direito do Trabalho deve ser realizado com cautela. A priori, deve-se buscar a história do ramo jurídico trabalhista, que se iniciou e se transforma paulatinamente graças às lutas de classes, para uma melhor compreensão da lei. Deste modo, a concepção social necessita de pré-existir ao estudo da norma, pois assim se entenderá a real razão de ser de uma disposição legal. Feito isto, o passo seguinte está presente na interpretação dos princípios inerentes ao Direito e Processo do Trabalho. Tais princípios resguardam os mandamentos da Constituição Federal, garantindo direitos fundamentais ao trabalhador. Desta base, os profissionais da área não podem se distanciar. Isto porque os preceitos trabalhistas resguardam a essência da matéria, cuja desobediência acarreta na destruição do Direito do Trabalho em certo caso concreto. Sem obediência aos princípios não há o Direito Material e Processual trabalhista.

Apenas na terceira etapa que será elaborada a interpretação direta sobre a lei. Contudo, realizadas as outras fases de maneira correta, a compreensão da norma ficará muito mais clara. Nesta etapa, utilizar-se-ão também as regras de hermenêutica e integração de lacunas já explicadas nos tópicos acima. O preenchimento das omissões das normas trabalhistas ou sua melhor interpretação deve ser acompanhada de comparações entre os preceitos e normas omissas ou conflitantes, buscando para cada caso concreto a prevalência de determinado direito fundamental de maior importância naquela situação, sem se esquecer que existirão hipóteses de harmonia entre tais princípios, cedendo uma parcela de cada lado.

Sob estas disposições, não se pode utilizar o Novo Código de Processo Civil, ante sua aplicação suplementar ou subsidiária ao Processo do Trabalho, em casos em que o trabalhador fique desprotegido ou diante de uma condição menos benéfica, por exemplo. Além do mais, a celeridade e as regras eficientes de execução no Processo do Trabalho em hipótese alguma devem buscar regras do procedimento civil que serviriam apenas para prolongar desnecessariamente suas demandas. O uso do Novo Codex deve se embasar somente em casos que o trabalhador adquira melhores condições de tutelar seu direito, como ocorre com as regras da distribuição dinâmica do ônus da prova. 
Conclui-se, portanto, que para se aplicar regras de cunho processual, deve-se obedecer aos preceitos do Direito Material a que se está entrelaçado. Uma interpretação sólida sobre o sistema de leis e princípios do Direito do Trabalho permitirá que a tutela jurisdicional seja eficaz. Os magistrados podem decidir conforme seu livre convencimento, sendo a única ressalva a de que os julgamentos necessitem de uma motivação em conformidade com as disposições trabalhistas. Além disso, por mais que existam normas que possibilitem o uso do procedimento civil no Processo do Trabalho, os julgadores não são obrigados à utilização cega de artigos que apenas tardariam a tutela de um direito de caráter alimentar, como ocorreria se aplicados os institutos do incidente de desconsideração da personalidade jurídica.

\section{CONSIDERAÇÕES FINAIS}

A luta pela manutenção dos Direitos trabalhistas adquiridos permanece da mesma forma que as demais etapas da história. O proletariado pouco conquista, mas batalha muito para não perder sua humilde parcela de direitos. Não obstante, a luta dos trabalhadores depende da tutela do Estado para fazer cumprir as normas e princípios protetivos. Deste modo, a prestação jurisdicional para harmonizar as relações laborais nos conformes da Constituição se apresenta como a maneira prática de efetivação das leis sociais. Diferentemente do empregador, que possui respaldo legal para aplicar multas, dentre outras penalidades, o trabalhador apenas torna seu direito palpável através do Poder Judiciário e das negociações coletivas.

Sendo a prestação jurisdicional um meio capaz de assegurar os direitos trabalhistas, os julgadores devem interpretar as normas de modo justo e cientes da disparidade, presente na maioria dos casos, entre empregador e empregado. A hermenêutica, portanto, é instrumento essencial no cotidiano dos magistrados. Assim, como apontado nesta monografia, na presença de normas ou princípios conflitantes entre si, devem-se alcançar os preceitos máximos de cada polo divergente. Existindo regras novas como Código de Processo Civil em vigor, somente serão aplicadas suas disposições no campo trabalhista, caso o princípio da norma processual comum não seja divergente ao que preceitua o Processo do Trabalho e seu 
Direito Material. E mais, em havendo conflito entre princípios constitucionais, é preciso realizar um sopesamento entre eles, de forma que em cada caso concreto o princípio que se apresente mais essencial prevaleça.

Devido à importância social do Direito do Trabalho, seu processamento deve buscar a máxima celeridade possível. Normas burocráticas e o descaso com um julgamento eficiente, bem como atos protelatórios da parte que provavelmente não terá sua resistência à pretensão tutelada, devem inexistir durante o procedimento trabalhista. Os magistrados possuem importante papel na consecução da subsistência do trabalhador, não devendo utilizar normas burocráticas de fácil fundamentação, como no caso de se aplicar uma norma processual civil apenas por uma leitura literal do art. 15 desta e 769 da CLT. Ao defensor, cabe analisar o andamento processual a fim de proteger o trabalhador frente a interpretações equivocadas e métodos eivados de burocracia e lentidão, realizando as medidas judiciais cabíveis.

Na presença da fase executória no Processo do Trabalho, a cautela deverá ser redobrada. Isto pelo simples fato de que houve o conhecimento do direito do trabalhador, estando este harmonizado pelo trânsito em julgado. Neste momento processual, as discussões acerca da execução devem ser mínimas, existindo apenas para conter abusos e prejuízos injustos ao executado. Vale ressaltar, que na execução trabalhista a tutela jurisdicional e o amparo da lei tornam-se mais fortes para que o trabalhador possa enfim obter seu crédito alimentar. $\mathrm{O}$ julgador pode iniciar a fase executória de ofício, a lei limita as matérias de defesa do executado e expande a possibilidade de satisfação do crédito (como na hipótese de se penhorar até mesmo valores alimentares do executado na medida em que não fiquem lesadas injustamente ambas as partes da execução).

Dentre as medidas executórias para a satisfação do crédito trabalhista, a jurisprudência tem adotado o instituto da desconsideração da personalidade jurídica com o escopo de não deixar o credor sem a tutela jurisdicional frente à possibilidade da insuficiência de patrimônio da pessoa jurídica. Aplicando a desconsideração, há a proteção dos direitos do trabalhador, já que esta medida impede que o empregador transfira o patrimônio de sua empresa/sociedade para a pessoa natural, acarretando insuficiência de bens na fase de execução. Tamanha é a importância deste instituto para o Processo do Trabalho que se aplica a teoria de maior impacto no que se refere à desconsideração, a objetiva. Esta teoria disciplina a possibilidade 
de execução dos bens do sócio, independentemente se os atos deste violaram ou não o contrato, ou se houve abuso de poder. Basta que a pessoa jurídica não possua bens para ter início a execução aos bens do sócio.

Em contrapartida da celeridade inerente à execução trabalhista, o novo Código de Processo Civil estabeleceu uma nova modalidade de intervenção de terceiros: o incidente de desconsideração da personalidade jurídica. A matéria de defesa acerca deste instituto prioriza a tese de que sua aplicação será importante para assegurar o direito ao contraditório e ampla defesa do sócio. No âmbito civil, em que se encontram partes em patamares parecidos sem a presença de hipossuficiência, o incidente de desconsideração da personalidade jurídica apresenta ser um fator positivo. Todavia, é preciso compreender que a relação jurídica no Processo Civil não está acobertada por princípios que existem na seara trabalhista, os quais preponderam sobre o excesso de contraditório (como exemplo, a dignidade humana). Além do mais, a única condição existente para se desconsiderar a personalidade jurídica no procedimento trabalhista é a insuficiência de bens da pessoa jurídica, restando como matéria de defesa do sócio, na existência da desconsideração, a indicação do patrimônio da pessoa jurídica capaz de atender à execução trabalhista. Isto porque que a dívida trabalhista por parte do sócio é presumida desde a propositura da ação trabalhista, não ferindo o contraditório e a ampla defesa.

Com base nesses apontamentos, o incidente de desconsideração da personalidade jurídica não deve ser aplicado durante a execução trabalhista. E, como argumento para tanto, há de se elencar um rol de motivos: a) é contrário aos princípios fundamentais do Direito do Trabalho, pois não se trata de norma mais favorável ao trabalhador e nem mesmo proporcionará uma condição mais benéfica; b) desrespeita as regras de hermenêutica, tendo em vista que no conflito entre os princípios constitucionais do contraditório e dignidade humana, o último deve preponderar; c) fere o que preceitua os arts. 15 do Novo CPC e 769 da CLT, já que a suplementação não deve ser contrária ao que preceitua o Direito do Trabalho; d) difere da essência da execução trabalhista, pois o incidente prejudicará a celeridade e a força da prestação jurisdicional efetiva neste ramo; e) socialmente, resultará em danos aos trabalhadores, que além de aguardarem anos na fase de conhecimento terão de suportar o mesmo na execução, em detrimento de sua subsistência; f) sua aceitação será um dos primeiros passos para se flexibilizar normas trabalhistas, tendo em vista que sua aplicação motivará 
outras regras e legislações restritivas de direitos sociais, o que ocorrerá facilmente na situação econômica em que se encontra o País.

Sob essas circunstâncias, o uso do incidente da desconsideração da personalidade jurídica no procedimento trabalhista será uma afronta principiológica, interpretativa, legal e social.

Por fim, de necessidade ímpar, será a compreensão de alguns contrapontos referentes à tese defendida. Em que pese o contraditório e ampla defesa pleiteados no caso em questão, os argumentos no decorrer do trabalho fundamentam e demonstram que não será um pensamento válido no âmbito do Direito e Processo do Trabalho, bem como da hermenêutica. Contudo, não se pode negar que os defensores desse instituto também buscam, através dele, uma contenção dos abusos judiciais que tornam a execução injusta. Há casos de atos executórios, como a penhora, que não acompanham o curso legal, sendo arbitrários e excessivos. Sem contar a demora processual, que em alguns casos está relacionada ao ânimo do julgador.

Todavia, tal posicionamento, apesar de justificável, não deve se fundar para aplicação desse instituto. É evidente que situações como as mencionadas acima ocorrem, mas não são a maioria. E mesmo que o fossem, um profissional do Direito não pode combater um erro gerando outro maior ainda. $\mathrm{O}$ trabalhador não pode sofrer as consequências de uma minoria no Judiciário, tendo em vista que seu crédito alimentar lhe proporciona o mínimo de dignidade. Que se elaborem punições administrativas para conter abusos e protelações judiciais, mas sem lesionar aquele que necessita do Judiciário para fazer cumprir seus direitos constitucionais. Deste modo, o incidente da desconsideração da personalidade jurídica não será o melhor caminho para se atingir a justiça.

\section{REFERÊNCIAS BIBLIOGRÁFICAS}

AMARAL, Júlio Ricardo de Paula. Princípio da proteção: limitações à aplicação no direito do trabalho. Disponível em: http://portal.trt15.jus.br/documents/124965/125408/Rev17Art 14.pdf/6fb77bea-ce51-468f-8e09-9201b5b434b4. Acesso em: 12 fevereiro 2016;

ALMEIDA, Cléber Lúcio de. Incidente de desconsideração da personalidade jurídica; 
BOTIJA, Eugenio Pérez, "Derecho del trabajo", apud LIMA, Francisco Meton Marques de. "Princípios de direito do trabalho na lei e na jurisprudência";

BOBBIO, Noberto. Teoria da norma jurídica. Traduzido por Fernando Pavan Baptista e Ariani Bueno Sudatti. Câmara Brasileira do Livro, $2^{\mathrm{a}}$ ed. , 2003;

CAMPOS, Francisco. A reforma do processo civil. Revista Forense. Rio de Janeiro: Forense. 1939;

CARVALHO, Orlando de. A teoria geral da relação jurídica - Seu sentido e limites. Coimbra: Centelha, 1981;

DELGADO, Maurício Godinho. Funções do Direito do Trabalho no Capitalismo e na Democracia. Estudos aprofundados da magistratura do trabalho. JusPODIVM. $2^{\text {a }}$ ed. Salvador-BA.

FINATI, Cláudio Roberto. O valor social do trabalho. Revista do Tribunal Regional do Trabalho da $1^{\mathrm{a}}$ Região, São Paulo: LTr, n. 8, p. 28-39, 1996;

FELICIANO, Guilherme Guimarães. Revista do Tribunal Regional do Trabalho da $\mathbf{1 5}^{\mathbf{a}}$ Região, n. 43, 2013;

GRINOVER, Ada Pellegrini. Teoria Geral do Processo, Malheiros Editores, $22^{\mathrm{a}}$ ed;

Jornal Trabalhista, São Paulo, Consulex, v. 20, n. 961, p. 12-13, 2003;

JÚNIOR, Nelson Neri. Comentários ao novo Código de Processo Civil. 1 ed. Rio de Janeiro: Forense. 2015.

LIMA, Francisco Meton Marques de. Princípios de direito do trabalho na lei e na jurisprudência;

MAIOR, Jorge Luiz Souto. Relação entre Processo Civil e Processo do Trabalho. Novo Código de Processo Civil e seus Reflexos no Processo do Trabalho, JusPODVM, 2015;

NOGUEIRA, Eliana dos Santos Alves. Incidente de Desconsideração da Personalidade Jurídica;

SILVA, José Antônio Ribeiro de Oliveira. Comentários ao Novo CPC e sua Aplicação ao Processo do Trabalho. LTr 80, São Paulo, 2016.

STUCHI, Victor Hugo Nazário. A valorização do trabalho humano como forma de realização do ideal de justiça social. Revista Eletrônica Scientia Faer, Olimpia: Faculdade Ernesto Riscali, Ano 2, v. $2,1^{\circ}$ sem., 2010.

SÜSSEKIND, Arnaldo; MARANHÃO, Délio; VIANNA, Segadas; TEIXEIRA FILHO, João de Lima. "Instituições de direito do trabalho"; 
